\title{
SPRITUALITAS YESUS
}

\author{
Nur Fitriyana \\ Fakultas Ushuluddin dan Pemikiran Islam \\ Nurfitriyana_uin@radenfatah.ac.id
}

\begin{abstract}
Jesus has spiritual revolution but he is not a political revolutionist. He did not try to reform the ruler in his time. The revolution in the sense of Jesus was to lift up the God values in this time. It is called as the social revolution. The revolution means the social repentance in the context of social relation. Jesus as the man of weak Jewish society in the time hoped to get the freedom of the Rome tyranny. Jesus was chosen as the social and spiritual revolutionist as the mission from God as the mission that was love Allah in the deepest heart and soul, love the people and the selves.
\end{abstract}

Keywords : jesus, spirituality, revolution

\begin{abstract}
Abstrak: Yesus memang melakukan revolusi spiritual namun ia bukanlah seorang revolusions dalam pengertian politik Ia tidak mencoba untuk merevolusi penguasa pada masanya. Revolusi dalam pengertian Yesus adalah mengangkat nilai-nilai Tuhan saat itu. Revolusi dalam pengertian ini adalah pertobatan sosial dalam konteks hubugan sosial. Yesus sebagai seorang anggota masyarakat yahudi yang tertindas memang berharap untuk mendapatkan kemerdekaan dari tirani Romawi Yesus dipilih sebagai seorang revolusionis dalam terma sosial spiritual yang memiliki misi dari Tuhan untuk mengasihi Allah dari lubuk hati yang terdalam, mengasihi manusia dan diri sendiri
\end{abstract}

Kata Kunci: yesus, spiritualitas, revolusi 


\section{A. Pendahuluan}

Dari keempat Injil kanonik, hanya dapat diketahui kehidupan Yesus ketika dilahirkan, dikhitan, diserahkan ke bait Allah, pemunculannya kembali di bait Allah pada usia 12 tahun, dan penampilan dirinya di depan umum setelah dibaptis oleh Yohanes. Kisah kelahirannya diceritakan secara paling lengkap dalam Injil Lukas dan Matius. Ketika Yesus memulai pekerjaannya kira-kira usia 30 tahun. Jadi ada waktu kosong selama 18 tahun antara usia 12 s/d 30 tahun. Kekosongan ini Menurut Armstrong ( 1993: 120) telah menyebabkan banyak penulis mencoba mengisinya menurut kepentingan mereka. Jelasnya selama berumur $12 \mathrm{~s} / \mathrm{d}$ 30 tahun, berdasarkan data Mat 13:55 dan Mark $6: 3$, Yesus menjalani kehidupan sebagimana layaknya anak-anak Yahudi dan ia bekerja bersama keluarganya sebagai tukang kayu. Mengapa kisah kehidupannya baru dicatat setelah usia 30 tahun ? menurut Yusuf Roni (2014: 22), karena memang demikianlah lazimnya kehidupan orang Yahudi. Kemudian berdasarkan informasi Dead Sea Scrolls (Naskah Laut Mati), seperti dikutip oleh Max I Dimont (1993: 99100), sepertinya mungkin, ia mempergunakan masa mudanya itu di biara Essene. Setelah kunjungan tersebut. Yesus menghilang dari lembaran-lembaran Injil. Kemudian Yesus muncul lagi di suatu tempat antara tahun 28-30 Masehi, pada umur 30 tahun. Yesus pergi ke tepi sungai Yordan tempat putra bibinya, Jhon (Yohanes). Seorang Nabi yang hidup sederhana. Jhon mengantarkan manusia kepada Kerajaan Allah, biasa membaptis jemaahnya dengan air untuk mensucikan dosa-dosa mereka. Mereka mengaku dosanya di muka umum.

Dari beberapa praktek keagamaan yang telah dilakukan Yesus dan orang tuanya bersumber kepada Injil, mencerminkan bahwa masa kecil dan masa muda Yesus kental dengan ajaran Taurat. Menurut Dennis Lardner Carmody dan John Tully Carmody (2000: 128) tidak dapat mengkontruksi kembali sebuah biografi Yesus. Selama tiga puluh tahun Yesus hidup di lingkungan kaumnya, sebelum mendapat risalah dan dipilih Allah. Selama itu tidak ada yang memandangnya kecuali hanya sebagai tukang kayu biasa yang terpercaya, makan dan minum.

Dari manusia biasa, kemudian Yesus tampil sebagai pembawa kabar gembira, bahwa Tuhan telah datang untuk menyelamatkan umat-Nya. Yesus berkeliling untuk memberi harapan dan iman kepercayaan kepada orang-orang. Iman itu mengangkat orang di atas kekuatannya sendiri, karena mempersatukannya dengan Allah. Menurut Konferensi Wali Gereja Indonesia (1996: 243), yang paling mengesankan dari kehidupan Yesus adalah tidak tergantung pada siapa pun. Para rabi pada zaman Yesus selalu mencari dukungan bagi ajaran 
mereka pada ajaran orang lain dari zaman dahulu. Yesus tidak, bahkan sebaliknya, "Kamu telah mendengar apa yang difirmankan kepada nenek moyang kita ...., tetapi aku berkata kepadamu " tidak " (Mat 5 : 21, 27, 31,33, 38 dan 43) Yesus tidak hanya berani melawan ajaran turun temurun, tetapi juga apa yang diimani sebagai ketetapan Allah sendiri. Terhadap tradisi manusiawi ia bahkan lebih tegas lagi. Sungguh pandai kamu mengesampingkan perintah Allah, supaya kamu dapat memelihara adat istiadat mu sendiri. Jelasnya pandangan hidup Yesus bukan adat istiadat atau ajaran tradisional agama, melainkan kesatuan pribadinya dengan Allah....Tidak ada seorang pun yang telah naik ke surga selain dia yang telah turun dari surga (Yoh $3: 13$ )

Dengan demikian, apa yang dipraktekkan oleh Yesus kelihatannya dapat dikategorikan sebagai praktek dari spiritulitas. Hal ini senada dengan yang diungkapkan oleh A.Heuken ( 2005: 106-107) Sprititualitas pada umumnya dimaksudkan sebagai hubungan pribadi seorang beriman dengan Allahnya dan aneka perwujudannya dalam sikap dan perbuatannya

Sering orang Kristen menurut Thomas Michel (2005: 125) berbicara tentang spiritualitas cara-cara atau program yang menyeluruh dari hidup Kristiani yang umumnya mencakup unsur mistik. Tiap tradisi spiritual Kristiani mempunyai tujuan untuk secara sempurna mengikuti apa yang diajarkan dalam kitab-kitab Injil dan disebut dengan jalan atau lorong Injil. Bisa dikatakan bahwa spiritualitas suatu program untuk menyelaraskan dari implikasi-implikasi mengikuti Yesus dalam setiap aspek kehidupan.

Dalam hal ini hanya ada satu spritualitas Kristiani, yakni menanggapi sepenuhnya apa yang Allah ajarkan dalam al-Kitab. Spritualitas Kristiani adalah suatu kesadaran bahwa menanggapi Allah harus mencakup dua dimensi yakni vertikal dan horisontal. Keduanya tidak boleh ada yang kurang dalam penghayatan hidup Kristiani yang diintegrasikan secara penuh. Dimensi vertikal adalah pemujaan dan doa, tugas dan kewajiban umat Kristiani kepada Allah. Dimensi horizontal mencakup tanggungjawab atas diri pribadi, atas sesama dan masyarakat. Meskipun secara dasariah hanya ada satu spiritualitas Kristiani, yang di acu baik oleh Gereja Ortodoks, Katolik dan Protestan. Sejarah Kristiani mengenal bermacam-macam gerakan spiritualitas yang menekankan aspek-aspek pesan al-Kitab tertentu atau menyediakan metode khusus dalam mengikuti Injil.

Jelasnya penting untuk diketahui setelah turunnya Yesus dari surga, Yesus mewartakan dan memberi kesaksian tentang Kerajaan Allah. Yesus bergaul dan membebaskan manusia dari beban dan persoalan kehidupan. Orang-orang yang mendapat perhatian Yesus disebut dengan berbagai istilah dalam Injil, yaitu miskin, buta, lumpuh, 
pincang, kusta, lapar, sengsara, pendosa, pelacur, pemungut cukai, kerasukan setan (dikuasai roh jahat), teraniaya, tertindas, terpenjara, yang bebannya terlalu berat, rakyat gembel yang tidak tahu hukum, orang banyak, orang kecil, yang terakhir anak-anak atau domba-domba yang hilang dari Israil. Menurut Albert Nolan ( 2005: 50) Yesus menyebut mereka sebagai orang-orang miskin dan kecil. Kelompok ini oleh orang Farisi sebagai pendosa atau rakyat gembel yang tidak tahu apa-apa mengenai hukum.

Dengan demikian penelitian ini dipandang penting agar diketahui secara lebih jelas dan komprehensif makna spiritulitas Yesus. Karena kajian yang mendalam tentang hal ini sangat penting, terutama dalam rangka memahami dan membongkar paham spritualitas yang selama ini cendrung ditampilkan dalam wajah eksklusif dan isolatif.

\section{B. Mengasihi Allah dengan Segenap hati, jiwa dan kekuatan}

Bersumber kepada Injil yang sinoptik, maka dapat diketahui bagaimana spiritualitas Yesus. Yesus mengutip shema ikrar pengakuan iman Yahudi yang paling agung. " Dengarlah hai orang Israil, Yahwe itu Allah kita, Yahwe itu Esa. Kasihilah Yahwe Allah mu dengan segenap hatimu, dengan segenap jiwamu dan dengan segenap kekuatanmu. (Ulangan: 6-4). Ia menambahkan bahwa perintah paling utama kedua yaitu mengasihi sesama manusia seperti mengasihi diri sendiri. Kelihatannya inilah inti dari spiritualitas Yesus. Pertama, mengasihi Allah dengan segenap hati, jiwa dan kekuatan. Kedua, mengasihi sesama manusia seperti mengasihi dirinya sendiri. Beberapa hal dibawah ini kelihatannya mencerminkan kedua aspek spiritualitas Yesus tersebut :'

\section{Mengasihi Allah dengan segenap hati, jiwa dan kekuatan}

Adapun implementasi dari aspek yang pertama, ini antara lain, yaitu

\subsection{Yesus konsisten untuk menyatakan beriman kepada Allah}

Ketika Yesus sedang lapar, tiba-tiba syetan datang menghasutnya supaya memohon kepada Allah merubah batu menjadi roti. Dalam Matius 4:4 Yesus menjawab : "Manusia hidup bukan dari roti saja, tetapi dari setiap firman yang keluar dari mulut Allah. Pada kesempatan lain, syetan menggodanya agar Yesus mau mencobai Allah. Dalam Matius $4: 7$ Yesus menjawab : ...Janganlah engkau mencobai Tuhan Allah mu.” Kemudian dalam Matius 4 : 8-10 menjelaskan, iblis membawa Yesus ke atas gunung dan memperlihatkan semua kerajaan dunia dan kemegahannya dan berkata kepadanya : semua itu akan kuberikan padamu, jika Engkau sujud menyembah aku. Maka berkatalah Yesus : “ Pergilah kau iblis ! Sebab ada tertulis engkau harus menyembah Tuhan, Allah mu dan hanya kepada Dia sajalah engkau berbakti ." 
Pada umumnya di setiap kesempatan Yesus bersikap tenang dan toleran dalam menghadapi kesulitan. Tetapi terkadang situasi membuatnya bersikap tegas dan keras. Dalam Yohanes 2 : 13-15, Matius $21: 12-13$ dan Markus $11: 15-16$ menjelaskan. Ketika hari raya paskah orang Yahudi sudah dekat, Yesus berangkat ke Yerussalem. Menurut James D. Tabor ( 2007 : 134) Yesus kerap menemukan simbol-simbol kekuasaan Romawi yang sangat menusuk hatinya. Yang bercampur dengan segala sesuatu yang dianggapnya sebagai puncak dari kebobrokan lembaga keagamaan Yahudi. Yerussalem yang didirikan Herodes lengkap dengan istana-istana teater, gelanggang pacuan kuda, rumah-rumah mewah serta bait Allah yang megah. Bagi orang lain mungkin ini salah satu keajaiban. Tetapi baginya kota itu sebagai sarang penyamun yang sebentar lagi di bawah penghakiman Ilahi.

Puncak dari kegusaran dan emosinya, hari Minggu Yesus secara terbuka memproklamirkan diri sebagai seorang yang berhak menduduki tahta Israil. Hari Senen Yesus menjungkirbalikkan, dan menghamburkan dagangan, meja-meja money changer serta menjatuhkan tempat kasir bagi pembayaran hewan kurban pada perayaan Paskah di Bait Allah ( temple of Jerussalem, kemudian ia mengutip kata-kata Yeremia dan Yesaya.(Yeremia 7 : 11) Sudahkah menjadi sarang penyamun di rumah yang atasnya nama-Ku diserukan ini ?( Yesaya 56:7) Dan Yesaya juga melihat suatu waktu Bait Allah di Yerussalem akan menjadi rumah doa bagi segala bangsa.” Hari selasa menurut James D. Tabor ( 2007 : 242-145) adalah hari yang penting bagi Yesus dan Dewan Dua Belas Murid. Mereka secara terbuka ke Bait Allah dan Yesus menghabiskan waktu seharian beradu argumen dengan berbagai segmen dari lembaga bait Allah termasuk imam Saduki, pemimpin Farisi dan kaum Herodian (pendukung Herodes). Para imam bertanya kepadanya : Dengan kuasa manakah engkau melakukan hal ini (dua tindakan kenabian yang dilakukan Yesus pada hari Minggu dan Senen) Yesus berkata bahwa ia akan menjawab mereka bila mereka di hadapan kerumuman orang banyak yang penuh minat mengikuti perdebatan itu berani menyatakan apakah Yohanes Pembaptis adalah seorang Nabi dari Allah atau seorang Penipu ? Para imam takut menjawab pertanyaan ini karena mereka menyadari popularitas Yohanes yang luar biasa. Kaum Farisi dan Herodian bertanya apakah Yesus menerima kewajiban pajak yang dibebankan oleh pemerintah Romawi. Mungkin hal ini menjadi masalah politis dan religius yang paling sensitif pada waktu itu. Sambil mengacungkan sekeping uang Romawi, ia menjawab pertanyaan tersebut dengan ungkapan yang terkenal dan bermakna: “ Berikan kepada kaisar apa yang wajib kamu berikan kepada kaisar dan kepada Allah apa yang wajib kamu berikan kepada Allah ." (Markus; 12:17) 
Hari itu Yesus mengungkapkan dua hal yang kelihatannya menjadi inti dari keseluruhan pandangannya tentang ibadah yang sejati. Seorang pria bertanya kepada Yesus tentang perintah Taurat yang paling utama. Yesus mengutip Shema ikrar pengakuan iman Yahudi yang paling agung. " Dengarlah hai orang Israil, Yahwe itu Allah kita, Yahwe itu Esa. Kasihilah Yahwe Allah mu dengan segenap hatimu dan dengan segenap jiwamu dan dengan segenap kekuatanmu. (Ulangan ; 6:4). Ia menambahkan bahwa perintah paling utama kedua yaitu mengasihi sesama manusia seperti mengasihi diri sendiri. Orang tersebut setuju, dan menyatakan bahwa bila seseorang mengasihi Allah dan mengasihi sesama manusia seperti ia mengasihi dirinya sendiri, maka semua itu jauh lebih utama dari semua korban bakaran dan korban sembelihan. Yesus kemudian menyatakan perkataan yang mengejutkan bagi orang tersebut. " Engkau tidak jauh dari Kerajaan Allah ( Markus 12: 28-34). Perkataan ini menunjukkan bahwa pandangan Yesus tentang Kerajaan Allah tidak hanya melibatkan pelengseran revolusioner terhadap kerajaan kerajaan dunia, tetapi juga wawasan rohani tertentu tentang hal-hal yang paling Allah inginkan dari manusia, yang satu tidak mungkin lengkap tanpa yang lain. Ketika hari makin sore, banyak orang berbaris untuk memberikan uang persembahan mereka ke dalam perbendaharaan bait Allah. Yesus melihat dan mengamati seorang janda miskin hanya membawa dua peser.( koin peser dikenal dengan nama lepton, upah harian bagi buruh kasar adalah satu dinar, satu dinar sama dengan seratus koin peser.) Hanya itu yang dimilikinya. Ia berkata kepada kerumunan orang banyak, Sesungguhnya janda miskin ini memberi lebih banyak dari semua orang yang memasukkan uang ke dalam peti persembahan. (Markus 12:43) Kondisi di atas sangat relevan ketika ia menghadapi cobaan di padang gurun (Matius 4-11 dan Lukas 4 : 1-13) Yesus mengajarkan bahwa seluruh ajaran Hukum (Taurat) dan para nabi dapat diringkas dalam dua perintah yaitu : (1) Kasihilah Tuhan Allah mu dengan segenap hatimu, segenap jiwa raga mu dan segenap budi mu. (2) Kasihilah sesamamu seperti dirimu sendiri. Hukum kasih ini begitu sentral, menurut Yusuf Roni (2014: 22) sampai Paulus mengatakan bahwa kalau sampai ada orang yang dapat memahami semua misteri teologi, melakukan hal-hal besar sampai martir karena imannya, tetapi tidak melakukannya dalam kasih, semua itu sia-sia.

Kalau dicermati, mengapa umat Kristen sekarang bukan lagi mempercayai Allah Yang Maha Esa, padahal Di dalam Perjanjian lama dan Perjanjian Baru jelas tidak ditemukan istilah Tritunggal atau Trinitas, Dalam buku Encylopedia of Religion seperti dikutip Teana Legamisi (t.t.: 8) mengakui: "The religion today are in agreement that the Hebrew Bible doesn't contain a doctrine of the Trinity" (Para ilmuwan Kristen sepakat, bahwa ajaran Trinitas tidak ada dalam al-Kitab bahasa Ibrani (Perjanjian Lama). Selanjutnya dalam buku New Catholic 
Encylopedia juga mengatakan: The Doctrine of the Holy Trinity isn't taught in the Old Testament (Ajaran Trinitas tidak pernah diajarkan dalam Perjanjian Lama). Dengan demikian, jelaslah dalam Kitab-kitab Perjanjian Lama hanya mengajarkan tentang Allah yang Esa, di antaranya, yaitu :

(i) Dalam Yesaya 44: 6 dikatakan: "Beginilah firman Tuhan, Raja dan Penebus Israil, Tuhan semesta alam. Aku-lah terdahulu dan Aku-lah yang kemudian. Tidak ada Allah selain dari pada Aku."

(ii) Dalam Yesaya 46: 9 dikatakan: "Ingatlah hal-hal yang dahulu dari sejak purbakala, bahwasanya Akulah Allah, dan tidak ada yang seperti Aku."

(iii) Dalam Ulangan 4: 39 dikatakan: "Sebab itu ketahuilah pada hari ini dan camkanlah, bahwa Tuhan Allah yang di langit di atas dan di bumi di bawah, tidak ada yang lain."

(iv) Dalam Ulangan 6: 4 dikatakan: "Dengarlah Hai Israil, Allah Tuhan kita, Tuhan itu Esa."

Kemudian dalam Perjanjian Baru, Yesus mengajarkan, seperti terdapat :

(i) Dalam Markus 12: 28-29 dikatakan: "Lalu seorang ahli Taurat, yang mendengar Yesus dan seorang Saduki bersoal jawab dan tahu, bahwa Yesus memberi jawaban yang tepat kepada orang-orang itu, datang kepada-Nya dan bertanya: "Hukum manakah yang paling utama?" Jawab Yesus: "Hukum yang terutama ialah, dengarlah, hai orang Israil, Allah kita, Tuhan itu Esa."

(ii) Dalam Yohanes 17: 3 dikatakan: "Inilah hidup yang kekal itu, yaitu bahwa mereka Mengenal Engkau, satu-satunya Allah Yang Benar, dan mengenal Yesus Kristus yang telah Engkau utus."

Dengan demikian, baik dalam Perjanjian Lama maupun dalam Perjanjian Baru, bahwa Musa as dan Yesus (Isa as) dengan tegas mengajarkan bahwa Tuhan manusia adalah Allah dan Allah itu Esa. Meskipun demikian, menurut keyakinan umat Kristiani, dasar-dasar tentang doktrin ini ditemukan dalam Perjanjian Baru, dalam Injil Matius 28: 19 dikatakan, "Karena itu pergilah jadikanlah semua bangsa murid-Ku dan baptislah mereka dalam nama Bapa, Putra dan Roh Kudus.”

Sebenarnya jika umat Kristiani mau jujur, Injil Matius pasal 28 berakhir pada ayat 15, sedangkan lima ayat berikutnya yaitu Matius 28: 16-20 adalah ayat-ayat yang baru ditambahkan oleh Gereja kemudian. Mereka yang berpikir logis dan membaca pasal 28 ini dengan cermat akan segera mendeteksi bahwa Injil Matius 28: 15 merupakan penutup Injil ini, yaitu: "Mereka menerima uang itu dan berbuat seperti yang dipesankan kepada mereka. Dan cerita ini tersiar di antara orang Yahudi sampai saat ini." Perhatikan kata-kata yang bercetak tebal di atas. Cerita ini tersiar sampai saat ini menunjukkan bahwa peristiwanya 
sudah lama berlalu. Ini memperlihatkan bahwa Injil ini sudah lama selesai ditulis. Cerita ini sudah menjadi cerita rakyat yang terus dipupuk selama puluhan tahun, baru kemudian ayat 1620 ditambahkan. Namun kemudian Gereja menambah-kan ayat-ayat sesudah 28: 15.

Dalam hal ini salah seorang pakar al-Kitab dan sejarah Pemikiran Kristen, hugh J. Schonfield, nominator pemenang Hadiah Nobel tahun 1959 dalam bukunya The Original New Testament hal. 124 dalam Teana Legamisi (t.t.: 12) mengatakan: "This (Matthew 28: 15) would appear to be the endof the Gospel (of Matthew). What follow (Matthew 28: 16 -20) from the nature of what is said, would then be a latter addition." Ayat ini (Matius 28: 15) nampak sebagai penutup Injil (Matius). Dengan demikian ayat-ayat selanjutnya (Matius 28: 16-20) dari kandungan isinya, nampak sebagai (ayat-ayat) yang baru ditambahkan kemudian.

Selanjutnya, Robert Funk, salah seorang Guru Besar Ilmu Perjanjian Baru, Universitas Harvard, dalam bukunya The Five Gospel, mengomentari ayat-ayat tambahan ini seperti dikutip Teana Legamisi (Ibid). Sebagai berikut: “The great commision in Matthew 28: 18-20 have been created by yhe individual evangelist... reflect the evangelist idea of lauching a world mission of the church. Jesus probably had no of launching a world mission and certainly was not the institution builder. (It is) not reflect direct instruction from Jesus." (Perintah utama dalam Matius 28: 18-20 ... diciptakan oleh para penginjil ... memperlihatkan ide untuk menyebarkan ajaran Kristen ke seluruh dunia. Yesus sangat mungkin tidak memiliki ide untuk mengajarkan ajarannya ke seluruh dunia dan (Yesus) sudah pasti bukan pendiri lembaga ini (agama Kristen). (Ayat ini) tidak menggambarkan perintah yang diucapkan Yesus.

Jika dicermati keterangan di atas, maka al-Qur'an telah menjelaskan bahwa semua nabi mempunyai misi yang sama, yaitu mengajarkan Allah itu Esa, termasuk Yesus (Nabi Isa as). Dalam hal ini Allah berfirman dalam QS. An-Nisa: 170, artinya: "Hai ahli Kitab, janganlah kamu melewati batas dalam agamamu dan janganlah kamu berkata atas Allah kecuali perkataan yang benar. Al-Masih anak Maryam itu tidak lain melainkan pesuruh Allah dan (bukti) bagi perkataan-Nya disampaikan-Nya kepada Maryam dan (bukti lagi) tiupan roh dari pada-Nya. Sebab itu berimanlah kepada Allah dan Rasul-Nya dan janganlah kamu berkata: Tuhan itu (tiga). Berhentilah, karena yang demikian itu lebih baik bagi mu. Sesungguhnya Allah Tuhan Yang Maha Esa. Maha Suci Dia dari mempunyai anak. BagiNyalah apa yang ada di langit dan di bumi dan cukuplah Allah itu menjadi tempat berserah."

Berdasarkan ayat-ayat yang terdapat dalam Perjanjian Lama, Perjanjian Baru dan alQur'an, maka semakin jelaslah semua menjelaskan dan mengajarkan bahwa Allah itu Maha Esa. Dan semakin jelaslah pula konsep Trinitas adalah ajaran yang ditambahkan kemudian. 
Jika Matius 28: 19 itu diucapkan Yesus maka belum dapat dianggap sebagai rumusan Trinitas, sebab baru ada tiga Tuhan dan tidak dijelaskan bahwa yang tiga itu adalah satu hakikat, yaitu hakikat Ilahi.

\subsection{Yesus konsisten mentaati hukum Taurat}

Sebagai implementasi dari iman kepada Allah, maka Yesus pun konsisten dengan ajaran Taurat, bahkan dari sejak kecil Yesus dibesarkan dalam tradisi Yahudi seperti yang sudah dijelaskan sebelumnya. Dari catatan masa kecil Yesus sampai perdebatannya dengan orang Farisi dalam Markus 12 : 28-33, dapat dilacak bagaimana konsistensi Yesus dalam mempertahankan prinsip-prinsip Taurat. Tidak sedikit Yesus mengutip kitab-kitab Yahudi. Yesus memelihara syariat bangsa Yahudi dengan sungguh-sungguh dan kedatangannya justru untuk menyempurnakan syariat tersebut. Yesus sangat menghormati syariat Musa as. Hal ini terbukti pada injil Lukas 16: 17, Yesus mengatakan, "Lebih mudah langit dan bumi lenyap dari pada satu titik dari hukum Taurat lenyap.” Bagaimana Yesus dibesarkan dalam ajaran Taurat dan kemudian mengamalkan ajaran tersebut, sudah penulis tuliskan bab sebelumnya.

Menurut Max I Dimont (1993: 100), Yesus menjalani kehidupannya sebagai seorang guru, mengkhotbahkan sendiri Injil-Nya. Tidak ada apa pun yang berbeda (un-Jewish) di dalam ajaran-Nya. Dia adalah seorang liberal. Dia melawan semua ketidakadilan di dalam tradisi para nabi sebelumnya. Dia mengajarkan ketaatan kepada undang-undang Musa, belas kasih kepada para fakir miskin, kemurahan hati dan toleransi. Dia berbicara dengan lemah lembut dan penuh kasih. Dia seorang guru pembangkit semangat yang mengekspresikan diri sebagai kristal yang bening. Kaum jelata berduyun-duyun datang kepadanya untuk mendapatkan dan mencari kenyamanan di dalam impiannya.

Dalam Matius 5: 17-20 dan lihat juga Lukas 6: 27-36 Yesus menegaskan. “ Janganlah kamu menyangka bahwa Aku datang untuk meniadakan hukum Taurat atau kitab para nabi. Aku datang bukan untuk meniadakannya, melainkan untuk menggenapinya. Karena aku berkata kepada mu : Sesungguhnya selama belum lenyap langit dan bumi ini satu iota atau satu titik pun tidak akan ditiadakan dari hukum Taurat, sebelum semuanya terjadi. Karena itu siapa yang meniadakan salah satu perintah hukum Taurat sekalipun yang paling kecil dan mengajarkannya demikiannya kepada orang lain, ia akan menduduki tempat yang paling rendah di dalam Kerajaan Surga. Maka aku berkata kepada mu : Jika hidup keagamaanmu tidak lebih benar dari pada hidup keagamaaan ahli-ahli Taurat dan orang-orang Farisi, sesungguhnya kamu tidak akan masuk ke dalam Kerajaan Surga. (Matius 5: 17-20) 
Semua orang Yahudi dewasa dituntut untuk mengikuti beberapa perayaan keagamaan di Bait Allah, paling tidak ada tiga hari raya (Keluaran.23:14-17), dan (Yohanes 2:13, 23). Disamping itu untuk mengimplemantasikan hukum Taurat Yesus shalat, berdoa dan berpuasa.

\subsection{Cara beribadah yang dilakukan Yesus}

(1)Membasuh tangan dan kaki sebelum masuk ke rumah ibadah. Musa dan Harun serta anak-anaknya membasuh tangan dan kaki mereka dengan air dari dalamnya. Apabila mereka masuk ke dalam kemah pertemuan dan apabila mereka datang mendekati kepada mezhab itu, maka mereka membasuh kaki dan tangan seperti yang diperintahkan Tuhan kepada Musa ( Keluaran. 40:31-32) (2) Melepas Alas Kaki sebelum Masuk Rumah. “ Lalu ia berfirman : “ Janganlah datang dekat-dekat tinggalkanlah kasut mu dari kaki mu, sebab tempat dimana engkau berdiri adalah tanah yang kudus. (Keluaran 3:5) dan lihat juga Mazmur : 5:8) (3) Menghadap Kiblat. Tetapi aku, berkat kasih setia mu yang besar, aku akan masuk ke dalam rumah $\mathrm{Mu}$, sujud menyembah ke arah Bait $\mathrm{Mu}$ yang kudus dan takut akan Engkau (Mazmur 5-8) (4) Rukuk dan Sujud Rukuk dan sujud kepada Allah. Masuklah, marilah kita sujud menyembah, berlutut di hadapan Tuhan yang menjadikan kita.(Mazmur 95:6). Maka pergilah Musa dan Harun dari umat itu ke pintu kemah pertemuan, lalu sujud. Kemudian tampaklah kemuliaan Tuhan kepada mereka (Bilangan : 20-6) Dalam hal ini Matius 26: 39 menjelaskan, "Maka Dia maju sedikit, lalu sujud dan berdo'a: "Ya Bapa-Ku jikalau kiranya mungkin, biarlah cawan ini lalu pada $\mathrm{Ku}$, tetapi janganlah seperti yang Ku-kehendaki, melainkan seperti yang Engkau kehendaki.

\section{(1) Yesus Berdoa}

Untuk mengimplemantasikan hukum Taurat Yesus juga berdoa. Dalam Injil banyak diceritakan tentang ketaatan Yesus, yaitu dalam Matius 14 : 23 dijelaskan, :" dan setelah orang banyak disuruhnya pulang. Yesus naik ke atas gunung untuk berdoa seorang diri. Ketika hari sudah malam ia sendirian di situ. Dalam Markus 1:35 dijelaskan : " Pagi-pagi benar waktu hari masih gelap, Yesus bangun dan pergi keluar. Yesus pergi ke tempat sunyi dan berdoa di sana.” Dalam Lukas 22 : 39-44 dijelaskan : “ Lalu pergilah Yesus keluar kota sebagaimana biasa ke bukit Zaitun. Para murid mengikutinya. Setelah tiba Yesus berkata kepada mereka : "Berdoalah supaya kamu jangan jatuh ke tangan percobaan. Kemudian Yesus menjauhkan diri dari mereka kira-kira seperlempar batu jaraknya lalu ia berlutut dan berdoa : "Ya Bapa ku jikalau Engkau mau ambillah cawan ini dari pada ku, tetapi bukanlah kehendaku melainkan kehendak Mu lah yang terjadi." Kemudian dalam Matius 6 :5-15 dan 
lihat Lukas 11: 2-4. Yesus mengajarkan bagaimana cara berdoa, yaitu : (1) Apabila kamu berdoa, janganlah seperti orang munafik. Mereka suka mengucapkan doanya dengan berdiri dalam rumah-rumah ibadat dan pada tikungan jalan, supaya mereka dilihat orang. Aku berkata kepadamu : “Mereka sudah mendapat upahnya. (2) Tetapi jika engkau berdoa masuklah ke dalam kamar mu, tutuplah pintu dan berdoalah kepada Bapa mu yang ada ditempat tersembunyi. Maka Bapa mu melihat yang tersembunyi akan membalasnya kepada mu. (3) Lagi pula dalam doa itu janganlah kamu bertele-tele seperti orang yang tidak mengenal Allah. Mereka menyangka banyaknya kata-kata akan dikabulkan doanya. Jadi janganlah kamu seperti mereka, karena Bapa mu mengetahui apa yang kamu perlukan sebelum kamu meminta kepada Nya. (4) Karena itu berdoalah demikian : “ Bapa kami yang di surga, dikuduskanlah Nama Mu, datangkah Kerajaan Mu, jadilah kehendak Mu di bumi seperti di surga. Berikanlah kepada kami hari ini makanan yang secukupnya dan ampunilah kesalahan kami, seperti kami juga mengampuni kesalahan orang kepada kami, janganlah membawa kami kepada percobaan, tetapi lepaskanlah kami dari yang jahat. Karena Engkaulah yang empunya Kerajaan dan Kuasa. Kemulian sampai selama-lamanya. Amin.

\subsection{Puasa}

Maka Yesus di bawa Roh ke padang gurun untuk dicobai iblis. Setelah berpuasa empat puluh hari empat puluh malam, akhirnya laparlah Yesus. ( Matius :1-2). Dalam berpuasa ada beberapa hal yang diingatkan Yesus, yaitu : (1) Perumpamaan Yesus tentang orang Farisi yang sombong yang merasa moralnya lebih unggul dari pada orang lain mengungkapkan dengan jelas bahwa Allah menolak sikap seperti itu. (Lukas: 18:9-14) (2) Puasa hendaknya urusan pribadi antara seseorang dengan Allah dan hendaknya tidak mengumumkannya dengan orang lain. (3) Dan apabila kamu berpuasa, janganlah muram mukamu seperti orang munafik. Mereka merubah air mukanya supaya orang lain melihat bahwa mereka sedang berpuasa. Aku berkata kepadamu : “ Mereka sudah mendapat upahnya.(Matius : 6:16) (4) Tetapi apabila kamu berpuasa, minyakilah rambutmu dan cucilah mukamu, supaya jangan dilihat orang bahwa kamu sedang berpuasa, melainkan hanya oleh Bapa mu yang ada ditempat tersembunyi. Maka Bapa mu melihat yang tersembunyi akan membalasnya.

\subsection{Perbuatan baik untuk memperoleh hidup yang kekal}

Di dalam Injil Matius 19: 16-26, lihat juga Markus 10:17-27 dan Lukas 18:18-27. Ada seorang datang kepada Yesus dan bertanya : "Guru perbuatan baik apakah yang harus 
kuperbuat untuk memperoleh hidup yang kekal. Jawab Yesus : “Apa sebabnya engkau bertanya kepada ku tentang apa yang baik ?" Hanya satu yang baik, tetapi jika kau ingin masuk ke dalam, turutilah segala perintah Allah. Orang tersebut bertanya : "Perintah yang mana ?" Kata Yesus : “ Jangan membunuh, jangan berzina, jangan mencuri, jangan mengucapkan saksi dusta, hormatilah ayah dan ibumu, dan kasihilah sesamamu seperti diri mu sendiri. Orang tersebut berkata kepadanya : "Semua itu telah kuturuti apalagi yang kurang? “ Kata Yesus kepadanya : “ Jika engkau hendak sempurna, pergilah, jualllah segala milik mu dan berikanlah itu kepada orang miskin dan engkau akan memperoleh harta di surga. Kemudian datang kembali dan ikutilah aku. Ketika orang tersebut mendengar perkataan itu pergilah ia dengan sedih, sebab hartanya banyak. Yesus berkata kepada muridmuridnya : “ aku berkata kepada mu, sesungguhnya sukar sekali bagi seorang kaya untuk masuk ke dalam Kerajaan Surga. Sekali lagi aku berkata kepada mu lebih mudah seekor onta masuk ke lobang jarum dari pada seorang kaya yang masuk Kerajaan Allah. Ketika murid mendengar itu sangat gemparlah mereka dan berkata : “ Jika demikian, siapakah yang dapat diselamatkan?" Yesus memandang mereka dan berkata : “ Bagi manusia hal ini tidak mungkin, tetapi bagi Allah segala sesuatu mungkin. Sementara dalam Matius 5: 38-42, Yesus menegaskan kembali untuk rela hidup akan penyiksaan dan berbuat tidak dendam.

\subsection{Risalah Yesus khusus untuk Bani Israil}

Untuk mengimplemantasikan dua ibadah yang sejati tersebut, Yesus mengutus para muridnya. Ketika memulai misinya Yesus secara terang mengatakan risalahnya khusus untuk Bani Israil. Dalam Matius 15: 24 dikatakan, "Aku diutus hanya kepada domba Israil yang hilang dari umatnya. Dalam al-Qur;an para murid tersebut dikenal dengan Hawariyun. AlQuran telah menyatakan kata Hawariyun sebanyak lima kali dalam surat yang berbeda, yaitu pada QS Ali Imron ayat 52-58, Al-Maidah ayat 111-115, Ash-shaf : 14. Q.S. dan Az-Zukhruf 63-65. Hawariyun dengan makna sahabat, murid, serta pengikut Yesus tanpa menyebutkan jumlahnya. Firman Allah berkaitan keimanan anggota Al-Hawariyun dalam QS al-Maidah 111-115 Dan (ingatlah) ketika Aku(Allah)ilhamkan kepada orang-orang Hawariyiin(sahabatsahabat Nabi Isa):"Berimanlah kamu kepada Ku dan kepada Rasul Ku!" Mereka menjawab:"Kami telah beriman, dan saksikanlah, bahwa sesungguhnya kami orang-orang Islam (Muslim,yang menyerah diri kepada Allah)"Kepada para muridnya Yesus telah berjanji akan memberikan kedudukan yang lebih tinggi dari kedudukan kedua belas suku Israil yang dahulu dan akan mengangkat mereka sebagai hakim-hakim yang akan menghakimi kedua belas suku Israil tersebut, janji itu diucapkan ketika Isa menjawab pertanyaan Petrus. Hal ini 
terdapat pada Matius 19: 27-28, Yesus berkata, "Sesungguhnya pada waktu penciptaan kembali, apabila anak manusia bersemayam di tahta kemuliaan-Nya, akan duduk juga di atas dua belas tahta untuk menghakimi kedua belas suku Israil.

Kemudian Yesus juga menegaskan kepada para muridnya, untuk menyebarkan misinya hanya kepada Bangsa Israil. Menurut James D. Tabor ( 2007: 205-6) Pada musim semi tahun $29 \mathrm{M}$, Yesus membagi dua belas muridnya ke dalam enam kelompok masingmasing terdiri dari dua orang. Langkah ini bersifat strategis sekaligus berbahaya. Misinya menyebar ke seluruh negeri. Mereka harus berjalan tanpa didampingi siapapun dan tanpa membawa apapun kecuali hanya sebilah tongkat, sepasang sandal dan sehelai jubah. Yesus memerinrahkan muridnya. Hal ini terdapat pada Matius 10: 5-6. "Janganlah kamu menyimpang ke jalan bangsa lain atau masuk ke negeri orang Samaria, melainkan pergilah kamu kepada domba-domba yang hilang dari umat Israil.” Orang Samaria menurut C. Groenen (1989: 41) adalah campuran Yahudi dengan bangsa-bangsa lain.Meskipun menganut agama berdekatan dengan Yahudi, mereka hanya menerima Taurat Musa dan tidak mengakui bait Allah tetapi beribadah di Gunung Garizim. Dengan demikian, Yesus senantiasa menyampaikan ajarannya, baik dalam bentuk nasehat atau pun dalam bentuk wasiat, yakni agar mereka hanya berdakwah kepada Bangsa Israil. Bahkan Yesus juga menegaskan untuk tidak memasuki perkampung yang bukan Yahudi dalam menyampaikan misinya, meski pun bangsa-bangsa itu bertetangga dengan bangsa Yahudi. Dengan demikian apa yang dijelaskan oleh Injil Lukas di atas senada dengan informasi al-Quran, antara lain pada QS. as-Shaaf: 6. Dalam ayat ini Isa as menjelaskan, bahwa dia hanya seorang Rasul yang diutus oleh Allah. Kemudian pada QS al-Maidah: 116-117, Allah menjelaskan dialognya dengan Isa as. Pada hari kiamat. Allah berfirman: "Hai Isa putra Maryam, adakah engkau pernah mengatakan kepada manusia, ambillah aku dan ibuku menjadi dua Tuhan selain Allah?" Maka Isa as menjawab: "Maha Suci Engkau, ya Allah, tiadalah pantas aku mengatakan yang demikian, niscaya Engkau lebih mengetahui dan aku tidak mengetahui apa yang ada pada diri- $\mathrm{Mu}$, karena Engkau Maha Mengetahui dan aku tidak mengetahui apa yang ada pada diri-Mu, karena Engkau Maha mengetahui segala yang ghaib. Aku tidak mengatakan kepada mereka, melainkan apa yang telah Engkau perintahkan kepadaku, yaitu sembahlah oleh mu akan Allah, Tuhan-ku dan Tuhan-mu. Dan aku pun menjadi saksi atas mereka selama aku hidup. Ada pun setelah aku wafat, maka Engkau-lah yang mengawasi mereka. Engkau-lah yang mengawasi segala sesuatu. Demikianlah dialog yang terjadi antara Allah dan Isa as pada hari kiamat nanti. Pada intinya untuk menjelaskan hakikat kelahiran Isa as adalah sebagai Rasul untuk memberikan tuntunan kepada Bani Israil. 
Kemudian para murid akan mendatangi kota-kota dan desa untuk berseru. , : Bertobatlah karena kerajaan Allah sudah dekat. Lalu mereka akan menumpangkan tangan pada orang-orang yang sakit dan mengusir roh jahat dan setan-setan serta memproklmasikan Kerajaan Allah sudah dekat. Mereka hanya boleh menginap satu malam di rumah yang menerima kedatangannya. Langkah yang diambil Yesus merupakan sebuah serangan rohani yang bertujuan mendatangkan moment kehadiran Kerajaan Allah. Yesus memproklamasikan Tahun Rahmat Yahwe. Merujuk kepada pemahamannya terhadap teks para nabi sebelumnya,Tahun Rahmat Yahwe sudah hampir berakhir dan memberikan kesempatan terakhir kepada Bani Israil untuk memilih pertobatan atau pembinasaan. Tahun ini juga diikuti dengan pembalasan Allah akan menumbangkan kerajaan-kerajaan dunia melalui serangkaian manifestasi kosmis. Kemudian ia memilih tujuh puluh utusan dan membagi mereka ke dalam tim seperti kelompok sebelumnya. Misi yang diemban mereka pun sama dengan kelompok dua belas.

Mereka kembali dengan suka cita karena mampu kekuatan yang mampu mereka jalankan terhadap dunia demonik. Yesus memberitahu mereka : Aku melihat iblis jatuh seperti kilat dari langit (Lukas 10:18). Kemudian menurut John A.T. Robinsons ( $1985 ; 147$ ) Yesus memiliki pengikut inti sekitar seratus orang lebih. Pada musim gugur 29 M Yesus memperoleh berita bahwa lawan-lawannya di Yerussalem sedang mencari jalan untuk menangkap dan membunuhnya (Yohanes 7: 1). Kelihatannya para musuh ini adalah pemimpin bangsa Yahudi dari kelas aristokrat. Mereka mengangap Yohanes Pembaptis dan Yesus sebagai ancaman terhadap kekuasaan dan kontrol mereka, baik atas tatanam ekonomi di bait Allah maupun dalam hal pengaturan perkara keagamaan. Tetapi Yesus merasa belum waktunya untuk berkonfrontasi dengan mereka. Ia memutuskan untuk menyebrangi sungai Yordan ke Dekapolis. Yesus menghabiskan musim dingin di sini. Yesus tidak merasa dipanggil untuk menyelamatkan Israil dengan mendorong orang untuk menerima baptis demi pengampunan dosa di Sungai Yordan. Ia mengambil keputusan ada yang lain yang perlu, sesuatu yang berhubungan dengan orang-orang miskin, sakit dan domba-domba yang hilang dari Israil.

\section{Mengasihi Sesama Manusia seperti Mengasihi Diri Sendiri.}

Aspek kedua dari pengamalan spiritulitas Yesus yang dirumuskan sebagai perintah paling utama kedua yaitu mengasihi sesama manusia seperti mengasihi diri sendiri. Seorang pria bertanya kepada Yesus tentang perintah Taurat yang paling utama. Yesus mengutip Shema ikrar pengakuan iman Yahudi yang paling agung, seperti yang sudah dituliskan di atas. 
Orang tersebut setuju, dan menyatakan bahwa bila seseorang mengasihi Allah dan mengasihi sesama manusia seperti ia mengasihi dirinya sendiri, maka semua itu jauh lebih utama dari semua korban bakaran dan korban sembelihan. Yesus kemudian menyatakan perkataan yang mengejutkan bagi orang tersebut. "Engkau tidak jauh dari Kerajaan Allah (Mrk 12: 28-34). Perkataan ini menunjukkan bahwa pandangan Yesus tentang Kerajaan Allah tidak hanya melibatkan pelengseran revolusioner terhadap kerajaan kerajaan dunia, tetapi juga wawasan rohani tertentu tentang hal-hal yang paling Allah inginkan dari manusia, yang satu tidak mungkin lengkap tanpa yang lain. Ketika hari makin sore, banyak orang berbaris untuk memberikan uang persembahan mereka ke dalam perbendaharaan bait Allah. Yesus melihat dan mengamati seorang janda miskin hanya membawa dua peser. ( koin peser dikenal dengan nama lepton, upah harian bagi buruh kasar adalah satu dinar, satu dinar sama dengan seratus koin peser.) Hanya itu yang dimilikinya. Ia berkata kepada kerumunan orang banyak, Sesungguhnya janda miskin ini memberi lebih banyak dari semua orang yang memasukkan uang ke dalam peti persembahan. (Markus 12:43) Kondisi di atas sangat relevan ketika ia menghadapi cobaan di padang gurun (Matius 4-11 dan Lukas 4 : 1-13) ajaran Yesus tentang kedua hal pokok di atas, sebagai hukum kasih begitu sentral, menurut Yusuf Roni (2014: 22) sampai Paulus mengatakan bahwa kalau sampai ada orang yang dapat memahami semua misteri teologi, melakukan hal-hal besar sampai martir karena imannya, tetapi tidak melakukannya dalam kasih, semua itu sia-sia.

Yesus tidak merasa dipanggil untuk menyelamatkan Israil dengan mendorong orang untuk menerima baptis demi pengampunan dosa di Sungai Yordan. Ia mengambil keputusan ada yang lain yang perlu, sesuatu yang berhubungan dengan orang-orang miskin, orang sakit dan domba-domba yang hilang dari Israil dan orang-orang yang berdosa.

\section{Orang-Orang Miskin}

Meskipun istilah miskin dalam Injil tidak hanya menunjuk orang-orang yang secara ekonomi kekurangan. Orang miskin dimaksud menurut Albert Nolan (2005: 51-52) diantaranya : (1) pengemis, orang-orang ini menderita sakit dan cacat hingga terpaksa mengemis karena tidak mungkin memperoleh pekerjaan atau karena tidak mempunyai keluarga yang mampu mengurusnya. Pasti tidak ada rumah sakit dan jaminan sosial. Mereka tidak bisa lain kecuali mengemis untuk mengisi perut mereka. Demikian juga orang buta, bisu, tuli, lumpuh, pincang dan sakit kusta biasanya adalah pengemis. (2) Janda dan anak yatim. Mereka tidak mempunyai saudara yang memberi jamianan hidup dan dalam masyarakat tidak mempunyai kemungkinan bekerja untuk mencukupi kebutuhan hidup mereka sendiri. Hidup mereka tergantung pada derma orang saleh dan bendahara kenisah. (3) 
Buruh harian yang tidak mempunyai keahlian, yang sering kali tidak mempunyai pekerjaan, petani yang bekerja di ladang dan mungkin juga budak.

\section{Orang-Orang Berdosa}

Orang-orang berdosa tersingkir dari pergaulan sosial, orang yang menyimpang dari hukum dan warisan adat istiadat yang dipegang oleh kelas menengah (orang-orang terpelajar dan saleh, ahli kitab dan kaum Farisi), diperlakukan sebagai orang yang lebih rendah termasuk kelas bawah. Kelompok pendosa adalah satu kelas sosial tertentu, sama dengan kelompok sosial orang-orang miskin. Yang termasuk dalam kelompok orang-orang berdosa menurut Albert Nolan (2005: 53-54) (1) Orang-orang yang mempunyai pekerjaan tidak bersih seperti pelacur, pemungut cukai, perampok, penggembala, lintah darat dan penjudi. Pemungut pajak dianggap sebagai penipu dan pencuri karena pekerjaan mereka memberi hak kepada mereka untuk menentukan besarnya jumlah pajak yang harus dibayar orang, dan hak untuk memperoleh komisi untuk diri mereka sendiri. Banyak diantara mereka yang tidak jujur. Demikian juga penggembala dicurigai sering membawa gembala mereka masuk ke ladang orang lain dan mencuri, yang tentu saja seringkali benar. Oleh karena itu pekerjaan seperti ini memperoleh cap yang tidak baik. (2) Orang-orang yang tidak membayar sepersepuluh (sepersepuluh penghasilan) kepada para imam. (3) Orang-orang yang tidak peraturan hari sabat dan kebersihan ritual.(4) Orang-orang yang tidak terdidik dan buta huruf, yang dengan sendirinya tidak tahu hukum dn tidak berkesusilaan. Bahkan orang-orang Farisi yang terbuka seperti Hillel dianggap sebagai orang yang tidak mungkin mempunyai keutamaan dan kesalehan. (5) Orang-orang tahanan dan terpenjara.

Tidak ada jalan keluar praktis bagi pendosa. Secara teoritis pelacur dapat dibersihkan melalui proses pertobatan, pembersihan dan silih yang rumit. Untuk itu ia perlu uang. Uang yang didapat dengan cara tidak halal tidak dapat digunakan untuk itu. Uangnya kotor dan haram. Seorang pemungut pajak dapat meninggalkan pekerjaannya dan memberikan restitusi kepada semua orang yang pernah ia rugikan, ditambah seperlima dari jumlah itu. Orang yang tidak terdidik harus melewati proses pendidikan panjang sebelum ia boleh yakin bahwa dirinya bersih. Dengan demikian menjadi pendosa adalah nasib. Seseorang sudah ditentukan oleh nasib atau rencana Allah untuk menjadi rendah. Dengan demikian orang-orang ini menderita karena frustasi, merasa bersalah dan cemas. Mereka frustasi karena tahu bahwa mereka tidak akan pernah diterima dalam lingkungan orang terhormat. Yang mereka rasakan paling perlu adalah pengakuan dan kehormatan, hal yang tidak mungkin mereka peroleh. Orang-orang terpelajar mengatakan kepada mereka bahwa mereka mengecewakan Allah. 
Akibatnya rasa bersalah yang mendalam mendekati neorosis, yang mau tidak mau membuat mereka takut dan cemas mengenai berbagai macam hukuman Ilahi yang mungkin menimpa mereka.

Berdasarkan asumsi di atas, kelihatannya orang-orang miskin dan tertindas di zaman Yesus selalu mudah terserang penyakit. Hal ini bukan hanya kondisi fisik tempat mereka hidup akan tetapi karena kondisi psikilogis. Tampaknya banyak dari antara mereka menderita sakit mental, yang tampak dalam gejala-gejala psikosomatis seperti kelumpuhan dan kesulitan dalam berbicara.

Bagi orang-orang Yahudi dan dunia Timur kafir menurut Derrett seperti dikutip oleh Albert Nolan ( 2005: 55) tubuh adalah tempat kediaman roh. Allah meniupkan roh ke dalam diri manusia yang membuatnya hidup. Pada saat kematian roh ini meninggalkan tubuh. Selama hidupnya roh-roh lain dapat juga masuk ke dalam tubuh orang lain apakah roh baik atau roh jahat, roh kenajisan dan setan. Keadaan seseorang dapat dilihat dari tingkah lakunya. Kalau seseorang tampak bukan dirinya, kehilangan kendali atas dirinya maka dianggap jelas bahwa sesuatu sudah masuk ke dalam dirinya. Dengan demikian kelakukan dan penglihatan istimewa yang dialami para nabi akan membuat orang berfikir bahwa ia dikuasai oleh roh Tuhan, sebaliknya tingkah laku orang yang sakit mental membuat orang berfikir ia dikuasai oleh roh jahat.

\section{Menyembuhkan orang-orang yang sakit}

Gejala-gejala yang nampak dalam anak yang kerasukan setan dalam Injil adalah gejala-gejala yang mungkin dalam ilmu kedokteran modern disebut dengan epilepsi, dengan ciri membanting diri ke tanah atau api, tidak bisa bicara, tuli, kejang dan mulutnya berbusa (Markus: 9 :17-27). Orang yang kerasukan roh jahat yang mengguncangkan dirinya di sinagoge adalah penderita epilepsi (Markus : 1 :23-26). Orang yang kerasukan setan yang tinggal di kuburan bersama roh-roh orang mati jelas orang gila yang sedang kambuh. " Tidak ada seorang pun yang sanggup mengikatnya sekalipun dengan rantai-rantainya diputuskan dan belenggunya dimusnahkan. Sehingga tidak ada seorang pun yang cukup kuat untuk menjinakkannya. Siang malam ia berkeliaran di kuburan di bukit-bukit sambil berteriak dan memukul dirinya dengan batu, (Markus : 5:3-5) Jelaslah ia kerasukan roh najis atau roh jahat (Markus : 5 :2)

Beberapa penyakit fisik lainnya dan juga psikosomatis dianggap sebagai akibat roh jahat. Lukas menuliskan tentang seorang wanita yang lemah Dan tidak bisa berdiri karena dirasuki roh jahat yang melemahkan tubuhnya. " Ia sakit sampai bungkuk punggungnya dan 
tidak dapat berdiri tegak. Roh yang memasuki dan tinggal di dalam diri wanita itu yang membuatnya demikian. (Lukas : 13: 10-17). Ada juga roh yang membuat bisu dan tuli. Rohroh ini mengikat lidah dan menutup telinga hingga orang yang dirasukinya bisu dan tuli. (Markus: $9: 18-25,7: 35)$ Demam keras yang diderita oleh ibu mertua Simon tidak secara tegas disebut roh jahat, tetapi penyakit itu dipersonifikasikan. :" Yesus menghardik deman itu dan penyakit itupun meninggalkannya. (Lukas : 4 :39) Orang lumpuh yang diampuni dosanya (Markus : 2: 1-12) kelihatannya mengalami psikosomatis akibat rasa bersalah yang mendalam. Ia pun dapat dikatakan dikuasai oleh roh jahat yang melumpuhkan, meskipun Injil tidak dengan tegas menyatakannya.

Semua penyakit yang disebutkan di dalam Injil menurut Jeremias seperti dikutip oleh Albert Nolan ( 2005: 57) sekarang disebut gangguan fungsi. Penyakit-penyakit yang tampak dari luar di kulit tidak akan digambarkan dengan cara seperti itu. Penyakit ini lebih merupakan cacat tubuh dari pada roh yang diam di dalam tubuh. Seseorang yang menderita sakit apapun, yang membuatnya tidak bersih secara lahir disebut penderita kusta. Pada waktu itu kusta adalah istilah umum meliputi semua penyakit kulit, termasuk luka dan luka bakar. Seorang penderita kusta tidak dikuasai roh jahat, tetapi tubuhnya yang tidak bersih juga aklibat perbuatan dosa. Semua kemalangan, penyakit dan penderitaan adalah buruk. Itu semua derita yang dikehendaki oleh Allah sebagai hukuman atas dosa-dosa si penderita itu sendiri atau dosa orang lain dalam keluarga atau juga dosa nenek moyang. Dalam hal ini seseorang bertanya kepada Yesus, : “ Rabbi siapakah berbuat dosa,orang itu sendiri atau orang tuanya sehingga ia dilahirkan buta ?" (Yohanes 9: 2 dan lihat juga Lukas 13: 24).

Orang-orang miskin dan tertindas berada di bawah kekuasaan ahli kitab yang menumpukkan beban hukum mereka dan tidak pernah mengangkat satu jari pun untuk menyentuhnya. (Lukas 11 : 46) Mereka tidak diberi hak warga. Menurut Jeremias seperti dikutip Albert Nolan (2005: 59-69) tidak satu tugas terhormatpun yang diberikan kepada mereka dan mereka tidak diperkenankan menjadi saksi dalam pengadilan. Pendosa disingkirkan dari sinagoge. Sementara orang profesional, pemilik toko, pedagang, tukang kayu dan pencari ikan adalah terhormat dan termasuk kelas menengah. Kaum Farisi, Esseni dan Zelot adalah orang terpelajar dari kelas menengah. Kelompok yang memerintah adalah kelas atas yang kaya dan mewah termasuk keluarga Herodes, keluarga aristokrat (para imam ) yang hidup dari sepersepuluhan dan pajak kenisah dan aristokrat awam (tua-tua) yang memiliki sebagian besar tanah.

Yesus berasal dari kelas menengah, tetapi yang menarik ia bergaul dengan orangorang miskin, orang sakit dan domba-domba yang hilang dari Israil dan orang-orang yang 
berdosa. Apa yang membuat seorang Yesus mau bergaul dengan rakyat jelata yang tidak tahu apa-apa mengenai hukum. Jawabnya karena belas kasih. Tergeraklah hatinya oleh belas kasih kasihan kepada mereka dan ia menyembuhkan mereka ( Matius 14:14). Tegeraklah hati Yesus oleh belas kasihan kepada mereka karena mereka lelah dan terlantar seperti domba yang tidak digembala (Matius $9: 36$ dan Markus 6 :34). Ia tergerak oleh belas kasihan melihat air mata seorang janda di Nain dan berkata : “Jangan menangis.” (Lukas 7: 13) Jelas dikatakan bahwa hatinya tergerak oleh belas kasih kepada orang kusta (Markus 1 : 41) tergadap dua orang buta (Matius $20: 34$ ) dan terhadap orang yang tidak mempunyai apapun untuk di makan (Markus 8 :2). Dalam Injil Kanonik berulangkali Yesus mengatakan kepada mereka miskin : “Jangan menangis, jangan cemas, jangan takut. (Markus 5: 36, $6: 50$, Matius 6: 25-34, Markus 4 : 40 dan Lukas 10 : 41) Ketika orang kagum akan mukjizat yang terjadi atas anak Yairus, Yesus mengatakan bahwa anak ini perlu diberi makan ( Markus : 42-43)

Adapun cara penyembuhan yang Yesus lakukan yaitu : (1) Menggunakan ludah seperti umum dianggap berkhasiat. (Markus 7: 33-8 :23) (2) Membuat kontak fisik secara spontan dengan orang yang sakit, seperti menyentuh dan memegang tangan mereka dan meletakkan tangannya atas mereka. ( Markus $1: 31,41: 6: 56 ; 8$ :22-25) (3) Menggunakan doa secara spontan (Markus 9 :29 (4) Yesus selalu percaya pada kekuatan iman, Yesus selalu mengatakan : “Iman mu yang telah menyembuhkan engkau.” ( Matius 21:22)

Dengan demikian, Yesus tidak menggunakan rumus upacara atau mantera. Menurut Vermes seperti dikutip Albert Nolan ( 2005 : 64) Pada zaman itu keberhasilan para pengusir setan disebabkan oleh penggunaan rumus-rumus upacara kuno yang ditepati secara teliti. Upacara ini meliputi mantera atau jampi-jampi, tindakan simbolis, barang-barang tertentu. Di samping itu meskipun ada dokter atau tabib, tetapi jumlahnya kecil dan pengetahuan mereka tentang obat sangat terbatas. Apalagi orang miskin jarang sekali mampu membayar mereka.

Jelasnya jika Yohanes mengandalkan pembaptisan demi pertobatan, maka Yesus mengandalkan iman. Iman adalah kekuatan maha dahsyat. " Segala sesuatu adalah mungkin bagi Allah “ ( Markus 10 : 27) Segala sesuatu mungkin bagi siapa saja yang mempunyai iman. (Markus 17: 20)

Untuk mengimplematikan pengamalan spiritual yang kedua terkait dengan pergaulan Yesus dengan para pendosa,orang miskin dan berpenyakit, dapat diketahui dari keempat Injil kanonik. Beberapa hal yang dilakukan Yesus yaitu : (1)Bersahabat dengan penungut cukai dan orang berdosa ( Matius 11 : 19 (2) Yesus mengadakan perjamuan bersama dengan pendosa. (3) Yesus juga mengundang orang-orang Farisi dan orang-orang yang terhormat untuk makan bersama (Lukas 7 :36, 11 :37 dan 14 : 1). (4) Yesus selalu membesarkan hati 
mereka dengan mengatakan : "Jangan takut, jangan khawatir dan kuatkanlah hati mu. " ( Markus 5 : 36, 6 :50 dan Matius $6:$ 25-34, Lukas 12; 32 dan Yohanes $16: 33$ ) (5) Lukas 6 : 20-21 “ Berbahagaialah kamu yang miskin, karena kamulah yang empunya Kerajaan Allah. (6) Dosa dapat diampuni karena iman ( Lukas 7 : 48-50) (7) Dalam hal pengobatan Yesus menekannkan pentingnya iman dalam penyembuhan. (8) (Lk 10:38-42). Lebih lagi, Yesus bersahabat erat dengan Maria Magdala yang Ia ajar dan kirannya diajak berdiskusi banyak hal dengan dia pula. Ia tidak menjaga reptusinya dengan bergaul erat dengan para pelacur, atau menjadi skandal dalam masyarakat (Lk 7:39; Mt 11:19). Yesus tak pusing dengan reputasinya. Hal yang menjadi pusat perhatian Yesus adalah cara masyarakat memperlakukan para pelacur dan para wanita yang tertangkap basah berbuat zina, dengan tidak adil. Para lakilaki tak pernah diadili, tetapi hanya para wanita dipersalahkan dan dihukum serta dianggap pendosa.

Pertanyaaannya apakah mungkin orang-orang Farisi dan pengemis dapat dijamu di sekitar meja yang sama? Tentu saja mereka pada mulanya mereka enggan. Untuk mengatasi kebiasaan sosial ini Yesus memaksa para pengemis untuk datang dan Yesus sendiri menumpang di rumah mereka Dengan demikian, yang penting bukan hanya perjamuan makan bersamanya tetapi pengaruh dari perjamuan ini terhadap orang-orang miskin dan berdosa. Dengan menerima mereka makan bersama, Yesus sudah membebaskan dari rasa malu, rendah diri dan rasa berdosa. Kontak fisik yang terjadi ketika berbaring bersama-sama membuat mereka diterima dan merasa bersih.

Manusia mempunyai martabat yang sama. Yesus tidak ada kompromi pada keyakinannya bahwa semua orang sama dalam martabat dan nilai kemanusiaan. Ia memperlakukan orang buta, orang timpang, orang tersingkir dan para pengemis secara hormat, sebagaimana Ia memperlakukan orang yang tingkat statusnya tinggi dalam masyarakat. Ia menolak bahwa para wanita dan anak-anak tidak penting dan tingkatnya rendah di masyarakat. Inilah alasan mengapa Yesus membalikan pandangan masyarakat. Yesus memberikan tempat kepada para wanita sesuai dengan martabat dan nilai kemanusiaannya. Yesuslah satu-satunya guru yang berdiri teguh dengan menerima para wanita sebagai sahabat-sahabat dan para muridnya.

Dalam situasi di atas Yesus hadir. Spiritualitasnya bersifar revolusioner. Tetapi Yesus bukanlah revolusioner di dunia politik. Ia tidak bermaksud menggulingkan orang-orang yang sedang berkuasa. Dia melakukan revolusi dengan cara memandang relasi sosial dalam masyarakat. Yesus memandang dirinya sebagai Nabi yang mempunyai misi untuk melaksanakan revolusi pertobatann spiritual dan sosial. 
Yesus menegaskan "Setiap orang yang datang kepadaKu tetapi tidak membenci bapanya, ibu, isteri anak-anak, saudara-saudari, bahkan dirinya sendiri, ia tak pantas menjadi murid ku" (Lukas 14:26). sambil memandang sekeliling ia berkata: "Inilah ibuku dan saudarasaudara ku! Barangsiapa melakukan kehendak Allah dialah saudaraku dan ibuku" (Markus 3:33-35)

Yesus dilahirkan oleh seorang perawan suci melalui sunnahtullah yang berbeda dengan manusia pada umumnya. Meskipun demikian tetaplah pada sifat-sifat kemanusiaanya, seperti makan, minum, tidur, gusar, dan emosi

Terdapat dua hal yang menjadi inti dari spiritualitas Yesus. Pertama, mengasihi Allah dengan segenap hati, jiwa dan kekuatan. Kedua, mengasihi sesama manusia seperti mengasihi dirinya sendiri. Implementasi dari inti yang pertama Yesus konsisten menyatakan Allah Maha Esa, konsisten terhadap hukum Taurat, rukuk, sujud, berdoa dan puasa tidak membunuh, berzina, mencuri, tidak mengucapkan saksi dusta, menghormati ayah dan ibu. Implementasi dari inti kedua, Yesus melayani orang-orang miskin, orang sakit, orang-orang berdosa dan domba-domba yang hilang.

\section{Daftar Pustaka}

\section{Al-Kitab}

Adolf Heuken, Ensiklopedi Gereja, Jilid V, Jakarta, Cipta Loka Caraka, 1995

Armsrong, Karen, Sejarah Tuhan, 1993, Bandung, Mizan

Carmady, Dennis Lardner dan John Tully, Jejak Rohani Sang Guru Suci, Memahami Spritualitas Budha, Konfusius, Yesus dan Muhammad, 2000, Jakarta, Raja Grafindo Persada

Dimont, Max I,Desain Yahudi atau rekayasa Kehendak Tuhan, Terj., Jews, God and History, 1993, Bandung, Eraseni Media

Heuken. A. Ensiklopedi Gereja Jilid I, III, IV dan V, 1994, Jakarta, Yayasan Cipta Loka.

Konferensi Wali Gereja Indonesia, Iman Katolik, 1996, Jakarta, Obor Roni, Yusuf, Membangun Kristologi

Tabor, D James, Dinasti Yesus, Terj., 2007 Jakarta, Gramedia, 
